\title{
Implementation of Regional Regulation Number 12 Year 2018 Concerning Regional Retribution in Gunung Mas Regency in Calibration and Recalibration Services Charges (Case Study in Kurun District)
}

\author{
Wahyudi", Asmu'i, Muslih Amberi
}

Master of Governmental Science, Faculty of Social and Political Science, Lambung Mangkurat University, Jl. Brigjen H. Hasan Basri, Pangeran, Kec. Banjarmasin Utara, Kota Banjarmasin, Kalimantan Selatan 70123, Indonesia

\author{
DOI: $10.36348 /$ sjef.2020.v04i09.005 \\ | Received: 22.08.2020 | Accepted: 31.08.2020 | Published: 09.09.2020 \\ *Corresponding author: Wahyudi
}

\section{Abstract}

This study aims to determine the extent of the implementation of the Regional Regulation No. 12/2018 on Regional Levies in Gunung Mas Regency on Calibration/Recalibration Service Charges, and to find out the obstacles that occur in implementing these policies. This research is located in Kurun Subdistrict, Gunung Mas Regency. The data collection technique was carried out in three steps, namely: observation, interview, and documentation. The informants of this research consisted of: 1) Head of Consumer Protection and Metrology Division of the Industry and Trade Service of Gunung Mas Regency; 2) Head of Metrology Section; 3) Metrology Sector Staff; and 4) Traders who have received services and who will assess how the policies calibration/recalibration are applied. This study uses qualitative data analysis following the concept of Miles and Huberman's model with the theory of policy implementation according to Edward III. The results of the study show that the implementation of Regional Regulation Number 12 of 2018 concerning Retribution for Recalibration Services in Gunung Mas Regency is still not effective. This ineffectiveness occurs due to several obstacles, namely the absence of socialization from the Dinas regarding the SOP for implementing Recalibration services to the community. This also resulted in a lack of public knowledge about the policy, which hindered policy implementation. Limited funds are also an obstacle in the distribution of information to the public.

Keywords: Policy implementation, local retribution, calibration/recalibration services.

Copyright @ 2020: This is an open-access article distributed under the terms of the Creative Commons Attribution license which permits unrestricted use, distribution, and reproduction in any medium for non-commercial use (NonCommercial, or CC-BY-NC) provided the original author and source are credited.

\section{INTRODUCTION}

Realizing the implementation of a good regional regulation and autonomy, of course, will require sufficient funds. This causes financial problems to receive considerable attention in the implementation of regional autonomy, because every government activity must cost money. The greater the amount of money available, the more possibilities for activities or plans that can be carried out in accordance with the applicable authority. One of the ways to maximize the sources of income, namely by maximizing the potential of local retribution as a source of contributor to local revenue (PAD) in Gunung Mas Regency.

Regional levies are local levies as payment for services and/or provided by local governments for the benefit of individuals or entities. Retribution has tegenprestatie or return of services directly from the government [1]. One of the strategies of the Gunung Mas district government to pursue local retribution is through extensification of charges with the enactment of the Gunung Mas District Regulation Number 12 of 2018 concerning Regional Levies on October 22, 2018, where the Regional Government sees the potential for retribution from the calibration/recalibration service which is very large can increase local revenue (PAD).

Calibration according to Law Number 2 of 1981 concerning Legal Metrology is a matter of marking with valid calibration or invalid calibration, or providing written statements marked with valid calibration or invalid calibration, carried out by employees who are entitled to do so based on testing, which is carried out on measuring, measuring, weighing and unused equipment. Meanwhile, recalibration is a matter of marking periodically with valid calibration signs or invalid calibration signs or providing written statements that have valid calibration or invalid calibration marks, which is carried out by an employee who has the right to do so based on tests carried out on 
measuring instruments, measure, weigh, and equipment that has been calibrated.

The implementation process is one measure of the success of a policy. The success of implementing a policy can be measured by looking at the suitability between the implementer or application of the policy with the design, goals and objectives of the policy itself and giving a positive impact or result for solving the problems faced. Edward [2] mentions 4 factors that influence policy implementation, namely: 1) Communication: Transmission, clarity and consitenscy; 2) Resources: Staff, information, authority, facilities; 3) Disposition: Incentives, Staffing; 4) Biroucraties Structure: Standard operating procedures, Framentation.

The implementation of a policy will certainly never be separated from the things that hinder the implementation itself. As stated by Bambang Sunggono in the book Law and public policy, policy implementation [3] that there are 4 factors inhibiting the implementation of a policy, namely: 1) policy content, 2) information, 3) support, and 4) potential sharing. Based on the explanation above, the researchers are interested in raising the research title Implementation of Regional Regulation Number 12 of 2018 concerning Regional Levies in Gunung Mas Regency on Calibration/Recalibration Service Charges. This article is intended to describe the implementation of Regional Regulation Number 12 of 2018 on Regional Retribution and what are the obstacles in implementing the policy.

\section{RESEARCH METHODS}

This study uses a qualitative approach with a descriptive method that is intended to describe, explain, explain and interpret in detail how the implementation of the Regional Regulation No. 12/2018 on Regional Levies concerning Calibration/Recalibration Services and what are the obstacles in implementing the implementation of Regulatory policies. The area is through the existing factors. The location of this research is in Kurun District, Industry and Trade Service, Gunung Mas Regency. This is because the Department of Industry and Trade of Gunung Mas Regency is an agency that has an organizational structure in charge of metrological problems, which is contained in the main tasks and functions of the field of consumer protection and metrology.

The informants in this study are the Head of the Consumer Protection and Metrology Division of the Gunung Mas Regency Industry and Trade, the Head of the Metrology Section, Metrology Field Staff, and Traders who have received services and who will assess how the Calibration/Recalibration policy. As with the qualitative approach data collection steps, there are three steps of data collection, namely: 1) observation by systematically observing and recording the object of research, 2) direct and structured interviews by interviewing informants individually while still referring to the interview guide that is prepared openly, and 3) documentation by requesting related documents, either in the form of writing (diary, history or policy) or drawings (photos, live pictures, sketches, etc.).

Data analysis in a qualitative approach was carried out after data collection took place using the Miles and Huberman model which can be described as follows: 1) Data Reduction in the form of summarizing notes obtained from the field, selecting the main things related to the research topic, focuses on important things, looks for themes and patterns and is arranged systematically, 2) Display Data is a complex arrangement of information in a systematic and simple form so that it is easy to understand the meaning and meaning, and 3) Drawing conclusions or verification in the form of a concluding description or description of an object that was previously dim or dark so that after being examined it becomes clear.

\section{RESULTS AND DISCUSSION}

The implementation of Regional Regulation Number 12 of 2018 concerning Regional Levies in Gunung Mas Regency has been carried out since 2018, especially in the implementation of calibration/recalibration. The basis for this policy is Law Number 2 of 1981 concerning Legal Metrology and the issuance of Law Number 23 of 2014 concerning Regional Government and Regulation of the Minister of Trade Number 115 of 2018 concerning Legal Metrology Unit. This Regulation of the Minister of Trade regulates the procedures for implementing calibration/recalibration.

The SOP for the implementation of calibration/recalibration consists of requests for calibration/recalibration to the office, receiving applications and checking the scope of UML services, conducting TTU testing, filling in the notes, checking and signing SKHP, issuing SKHP and SKRD, giving UTTP and/or SKHP to mandatory TTU, and file TTU Documents. The results showed that there were four findings in the field in the implementation of the calibration service.

a) The traders have never submitted a letter of application for calibration/recalibration to the office.

b) The agency never received a letter of request from the traders.

c) Many traders do not know about the Recalibration policy.

d) Lack of funds for the implementation of socialization and for buying equipment for Recalibrating services.

Edward's theory suggests that there are four factors that influence the success or failure of policy implementation, namely communication, resources, dispositions and bureaucratic structures. 


\section{Communication}

Based on the results of research conducted by researchers, it shows that traders have never submitted an application for a calibration/recalibration application to the official. This occurs due to several things, namely: 1) communication between policy makers and communication between agencies and policy implementers. Communication between policymakers has been forwarded in a clear, accurate and consistent manner. This is reflected in the policy implementation guidelines that the implementers understand so that they know what to do and the policy provisions are also clear so that the implementers know how to implement the policy. As stated by Markurius, ST as the executor as well as the head of the section on consumer empowerment and metrology that "the guidelines for implementing policies regarding application for reregistration are clear and easy to understand" (Interview 2 February 2020). However, communication between the office and policy implementers has not been carried out properly. This can be seen from the results of an interview with Setiawan Trianto, $\mathrm{SH}$ who said that "there has never been any dissemination of policies regarding regional regulation number 12 of 2018 concerning regional levies in Gunung Mas Regency, especially regarding applications for calibration/recalibration, accepting applications and checking the Scope of Service. UML and socialization about Conducting TTU Testing, Filling in TTU Absorption" (interview 2 February 2020). This was also supported by Bainah, a trader in an interview on February 3, 2020 who said that "we were never informed of a definite request for recalibration after they repaired our scales, we pay for the local government, he said." The absence of socialization carried out by the agency resulted in public ignorance/lack of understanding of the policy.

\section{Resource}

Another factor that influences the successful implementation of a policy is resources. Resources and quality referred to here are human resources, information, authority, infrastructure and funding. One of the obstacles in implementing regional regulation number 12 of 2018 concerning regional levies in Gunung Mas regency on calibration/recalibration service fees is the lack of facilities to inform the policy, for example how an example of a calibration/recalibration application letter and other information related to the policy. The existence of limited funds to support or fulfill the required facilities is also an obstacle for local governments. As stated by Dra. Vonny Rita in an interview on February 1, 2020, "the unavailability of supporting facilities and specific sources of funds for implementing the application for recalibration policy is a separate obstacle for us, so we only use the existing facilities".

\section{Disposition}

The third factor that affects the successful implementation of a policy is disposition. The disposition in this study is seen from the character aspects and characteristics or attitudes possessed by the implementor such as commitment, honesty and democratic character. Based on the results of research conducted by researchers, it can be seen that the attitude of the executing apparatus of the Gunung Mas Regency trade and industry service has provided support, commitment, is honest and democratic in the implementation of this policy. This can be seen from the statement of Dra. Vonny Rita in an interview on February 1, 2020, that "basically we support the policy on application for calibration/recalibration as part of implementing calibration services in the regions". However, the attitude of the public / traders who are not committed and do not support the implementation of the policy is also one of the obstacles. As stated by Setiawan Trianto, SH. In an interview on February 2, 2020 that "Our Constraint is Traders Never Making a Request for calibration/recalibration".

\section{Bureaucratic Structure}

The last factor that affects the successful implementation of a policy is the bureaucratic structure. The bureaucracy as a whole is the implementer of policies. One aspect of the basic bureaucratic structure of government organizations is the Standard Operating Procedures (SOP). The use of SOPs can help implementers of the application of calibration/recalibration policies to make optimal use of time, SOPs also simplify complex legislative policies so that they are easy to understand and implement effectively by policy implementers. Judging from the implementation point of view, the SOP for calibration/recalibration application is clear and is in accordance with the rules and procedures made by the agency whose reference is to the Law and Regulation of the Minister of Trade. Even though the SOP is well structured, the absence of traders submitting a letter of application for calibration/recalibration causes the SOP process to not run smoothly.

Based on the explanation above, we can see that the biggest obstacle of all is the absence of the official to socialize calibration/recalibration services to the community, especially traders in the Kuala Kurun traditional market. Although this regional regulation has been implemented for a long time, it is still not effective. Actually, the department, especially the Metrology Sector, cannot be fully blamed for the ineffectiveness of implementing these regional regulations. Funds are one of the main factors for the smooth implementation of a policy. Lack of funds owned by the agency resulted in limited socialization and fulfillment of supporting facilities to facilitate the implementation of regional regulation number 12 of 2018 to the public. This results in many people who do not know about the meaning of calibration/recalibration 
and how the SOP for calibration/recalibration application. The absence of traders who asked to recalibrate the measuring and weighing instrument (UTTP) resulted in the SOP process not running properly. This certainly has an impact on the ineffectiveness of the implementation of regional regulation number 12 of 2018 concerning regional levies in Gunung Mas Regency on Calibration/Recalibration service fees.

\section{CONCLUSION}

Based on the results of research on the implementation of Regional Regulation Number 12 of 2018 , it can be said that it is still not effective. This can be seen from the fact that there are still many people who do not know about the mechanism for implementing the calibration/recalibration service, especially the SOP for calibration/recalibration application. The obstacle in the implementation of calibration/recalibration services in Gunung Mas Regency is seen from Edward's theory, namely the lack of socialization about the SOP for the implementation of calibration/recalibration services. This resulted in a lack of information obtained by the public regarding the implementation of Regional Regulation Number 12 of 2018. This lack of socialization occurred due to limited funds in conducting socialization and fulfilling the necessary supporting facilities to facilitate the implementation of these regional regulations. Lack of community commitment and support for this policy is also one of the obstacles in the implementation of Regional Regulation Number 12 of 2018. In addition, the absence of people submitting a letter of calibration/recalibration application results in the implementation of SOPs still unable to be as effective as it should be.

\section{REFERENCES}

1. Sudargo, R. (Ed.). (1964). Padjak-daerah dan retribusi-daerah. Eresco.

2. Edwards, III., \& George, C. (1980). Implementing public policy, Texas A \& $M$ University. Congressional Quarterly Press.

3. Sunggono, B. (1994). Hukum dan Kebijaksanaan publik. Sinar Grafika. 